\title{
新居浜選鉱工場における計測管理の現状
}

\author{
中㴔拓治*
}

\section{Instrumentation at Niihama Ore Dressing Plant}

Takuji NAKANUMA

新居浜選鉱工場において現在使用されている計測器に は次表のようなものがある。とのうちの一部について は、すでに昭和 31 年10月浮選研究会編「計測管理の現状
と効果の調査表」に発表されておるので、ここでは比較 的最近設置した濃度調節計、 $\mathrm{pH}$ 調節計およびポイドメ ーターについてその概要を発表する。

\begin{tabular}{|c|c|c|c|c|c|c|c|}
\hline & 計測器名称 & 計 測 器 型式 & 測 定 対 象 & 測定範囲 & 設置場所 & $\begin{array}{l}\text { 設備 } \\
\text { 台数 }\end{array}$ & 製 作 所 \\
\hline \multirow{5}{*}{ 重量 } & $\begin{array}{l}\text { コンベヤ } \\
\text { スケール }\end{array}$ & メリック スケール & 選鉱受入鉱 & $0 \sim 600 \mathrm{t} / \mathrm{h}$ & 受 & 1 & 川西機械 \\
\hline & $\begin{array}{l}\text { コンベヤ } \\
\text { スケール }\end{array}$ & メリックスケール & ミルビン 給 鉱 & $0 \sim 200 \mathrm{t} / \mathrm{h}$ & 破 & 1 & 川西 機 械 \\
\hline & ポイドメーター & $\begin{array}{c}\text { メリック スケール } \\
\text { シンクロ式 } \\
\text { 指示積算計 }\end{array}$ & ボールミル給鉱 & $20 \sim 30 \mathrm{t} / \mathrm{h}$ & 摩 & 4 & 久保田鉄工 \\
\hline & ポイドメーター & $\begin{array}{c}\text { メリック スケール } \\
\text { 電 子式 } \\
\text { 記録調節積算計 } \\
\end{array}$ & $\begin{array}{l}\text { トリコンミル } \\
\text { 給 鉱 }\end{array}$ & $2 \sim 8 \mathrm{t} / \mathrm{h}$ & $\begin{array}{l}\text { 硫化ニッケル } \\
\text { 選 鉱 }\end{array}$ & 1 & $\begin{array}{l}\text { 久保田 鉄工 } \\
\text { (計器は横河) }\end{array}$ \\
\hline & パルプ計重機 & $\begin{array}{l}\text { 自動振子式 } \\
\text { 科 量 積 算 計 }\end{array}$ & 銅精 鉱 & $1.04 \mathrm{t} / \mathrm{h}$ & $\begin{array}{l}\text { 硫化ニッケル } \\
\text { 選 鉱 }\end{array}$ & 1 & 大 和 製 衡 \\
\hline \multirow{3}{*}{$\begin{array}{l}\text { 濃度 } \\
\text { (比重) }\end{array}$} & 濃度計 & $\begin{array}{l}\text { 気泡管式 } \\
\text { マスコアダム調節計 }\end{array}$ & $\begin{array}{l}\text { スライム分級機 } \\
\text { 溢流鉱 }\end{array}$ & & 砕 & 1 & MASSCO \\
\hline & 濃 度計 & 気泡管式記録計 & 分級 機 溢流鉱 & $0 \sim 61.5 \%$ & $\begin{array}{l}\text { 硫化ニッケル } \\
\text { 選 } \quad \text { 鉱 }\end{array}$ & 1 & 島 \\
\hline & 濃度計 & 気泡管式記録調節計 & 浮 選 原 鉱 & $0 \sim 61.5 \%$ & $\begin{array}{l}\text { 硫化ニッケル } \\
\text { 選 鉱 }\end{array}$ & 1 & 島 \\
\hline \multirow{3}{*}{$\mathrm{pH}$} & $\mathrm{pH}$ & ガラス電極 記 録計 & 優先 浮選 原 鉱 & $6 \sim 13 \mathrm{pH}$ & 浮 & 1 & $\begin{array}{l}\text { Minneapolis- } \\
\text { Honeywell } \\
\text { Regurator Co. }\end{array}$ \\
\hline & $\mathrm{pH}$ & $\begin{array}{l}\text { ガラス電極 } \\
\text { 記 録 調 節 計 }\end{array}$ & 浮 選 原 鉱 & $3 \sim 13 \mathrm{pH}$ & $\begin{array}{l}\text { 硫化ニッケル } \\
\text { 選 鉱 }\end{array}$ & 1 & 大 倉 電 気 \\
\hline & $\mathrm{pH}$ & $\begin{array}{l}\text { ガラス電極 } \\
\text { 記 録 調 節 計 }\end{array}$ & 優先 浮選 原 鉱 & $6 \sim 13 \mathrm{pH}$ & 浮 & 1 & 大 倉 電 気 \\
\hline \multirow{2}{*}{ 流量 } & パルプ流量計 & 差圧式指 示 記 録 計 & 浮 選 パル プ & $\begin{array}{l}0 \sim 32 \\
\mathrm{~m}^{3} / \mathrm{h}\end{array}$ & 浮 & 1 & 島 \\
\hline & 空気流量計 & 差圧式指 示 記 録 計 & ブロワー風量 & $\begin{array}{l}0 \sim 800 \\
\mathrm{Nm}^{3} / \min \end{array}$ & 浮 & 1 & 島 \\
\hline
\end{tabular}




\section{I 濃度自動調節計}

本濃度計は株式会社島津製作所の製作にかかる差圧管 式のあので計器、発信器および調節弁の三つの部分によ り構成される。

以下その概要について述べる。

\section{1. 仕 様}

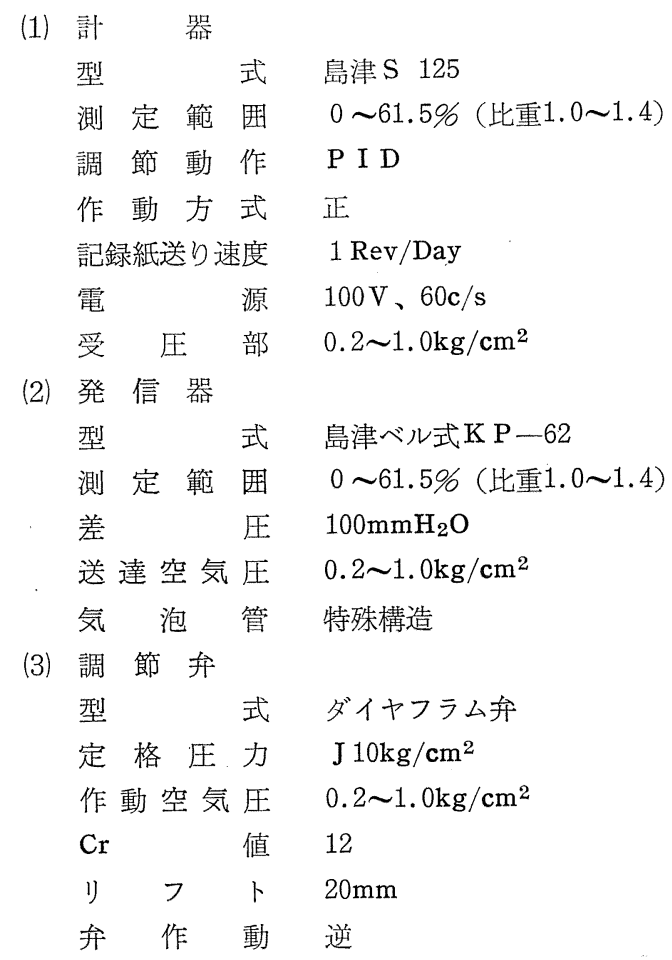

\section{2. 測定制御系統図 (第 1 図)}

3. 原理

槽内に長さの異なる 2 本の気泡管を、hなる深度差を 与えて設置し、エヤーパージセットを通じ一定量の空気 を流すと気泡管の先端から気泡となって液中に噴出す る。この時の両気泡管の背圧を基準液面槽を通じて測定 するととにより密度（鉱石の真比重一定として濃度）を 測定するととができる。即ち気泡管の背圧は液の密度を $\rho$ とすれば

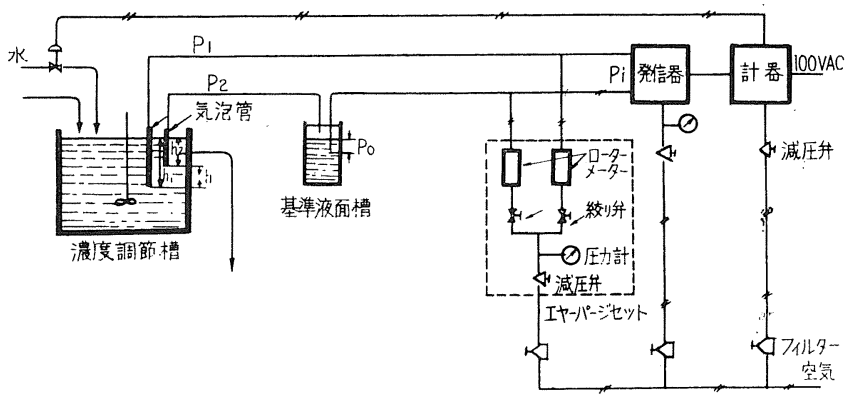

第1図測 定制 御 系 統 図
それぞれ $\mathrm{P}_{\mathbf{1}}=\rho \mathrm{h}_{\mathbf{1}}+\Delta \mathrm{P}_{\mathbf{1}}$

$$
\mathrm{P}_{2}=\rho \mathrm{h}_{2}+\Delta \mathrm{P}_{2}
$$

ここで $\Delta \mathrm{P}_{1} 、 \Delta \mathrm{P}_{2}$ は気泡が気泡管から離机るために要 する圧力で一般には微少である。

今、基準液面槽の圧力を $\mathrm{P}_{0}$ とすると、発信器に加加 万差压 $\mathrm{Pi}$ は $\mathrm{Pi}=\mathrm{P}_{1}-\left(\mathrm{P}_{2}+\mathrm{P}_{0}\right)=\rho\left(\mathrm{h}_{1}-\mathrm{h}_{2}\right)-\mathrm{P}_{0}$ $+\left(\Delta \mathrm{P}_{1}-\Delta \mathrm{P}_{2}\right)$ となり $\left(\Delta \mathrm{P}_{1}-\Delta \mathrm{P}_{2}\right)$ は微少であるの で、これを無視すれば $\mathrm{P}_{0} 、 \mathrm{~h}_{1}-\mathrm{h}_{2}$ を適当に選定し、 $\mathrm{Pi}$ を測定するととにより $\rho$ を測定するととができる。発信 器はこの $\mathrm{Pi}$ を測定し $0.2 \sim 1.0 \mathrm{~kg} / \mathrm{sm}^{2}$ の信号空気圧に 変換するあのであり、指示計がついている。信号空気圧 は計器に送られて記録ペンを動かせしめる。また記録ぺ ンと同軸に設計針があり、調節の目標設定值をこれで与 える之両者の差により調節計の入力が決まり、演算回路 を通って調節弁传空気圧が与えられる。調節動作は比例 と積分である。（との場合、微分動作は必要がない）

例えば槽内の濃度が高くなったとすると、計器の入力 信号が大きくなり、記録ペンと設定針の開き（偏差）も 大きくなるため、ダイヤフラム弁に行く空気圧が高くな り、弁をより多く開き水を入れ濃度を下げる。濃度が下 がれば逆治弁は閉じ平衡した位置で弁は静止する。比例 動作は制御偏差に比例して調節端を作動させる制御方式 で積分動作は比例動作により生じたオフセットを打消す ためのもので制御偏差の時間に関する積分値に比例して 調節端を作動させる。

\section{4. 特 長}

1. 塺埃、鉱石粉等を含んだ泥水状の液体に使用可。

2. 任意の範囲を適当に選んで測定できる。

3. 構造が簡単で取报いが便利である。

4. タイムラグが少ないので自動制御に使用できる。

\section{5. 据付使用後の現状}

昭和 36 年 5 月以降据付使用中であるが概水順調に作動 している。

\section{II $\quad$ pH 調節計（製作所……倉電気株式会社）}

\section{1. 仕 様}

（1）計器...電子管式帯型 $\mathrm{pH}$ 記録調節計

型式 $15 \mathrm{~S} \mathrm{C} 1$ - I R C

目 盛 $3 \sim 13 \mathrm{pH}(1$ 目盛 $0.2 \mathrm{pH})$

平衡速度 $10 \mathrm{sec}$

$$
\text { チャート巾 } 150 \mathrm{~mm}
$$

調節計用発信スライド、上下限警報接点付 電 源 $100 \mathrm{~V} \sim 60$ 。

(2) 前置増巾器

$\begin{array}{lll}\text { 型 } & \text { 式 } & \mathrm{AM}-103 \text { 、指示計付 } \\ \text { 目 } & \text { 盛 } & 3 \sim 13 \mathrm{pH}(1 \text { 目盛 } 0.2 \mathrm{pH}) \\ \text { 電 } & \text { 源 } & 100 \mathrm{~V} \sim 60 \sim\end{array}$

(3) 電気式調節計 
型 式 $\mathrm{EC}-2301$

制御動力 全電気式

制御方式連続式、比例、積分、微分 動作

比例 带２５00\%、単一ダイヤル操 作連続可変

微分時間 $0 \sim 8 \mathrm{~min}$

リ七ット率 $0.01 \sim 100 \mathrm{veps} / \mathrm{min}$ 、単一 ダイヤル18ステップ

消費電力 A C $100 \mathrm{~V}$ 、約 $50 \mathrm{~W}$

手 動 操 作 遠方手動操作可能

(4) 電 極

$$
\begin{array}{ll}
\text { ガラス電極 } & 0 \sim 12.5 \mathrm{pH} 、-5 \sim 60^{\circ} \mathrm{C} \\
\text { カロメル電極 } & \text { スリーブジャンクションタ } \\
& \text { イプ }
\end{array}
$$

温度補償補償範囲一 $5 \sim 100^{\circ} \mathrm{C}$

(5) 操 作 部

$$
\begin{array}{ll}
\text { パワードライブュニット } & \text { P D U-21A } \\
\text { マグモーター } & \text { 安川 } 200 \mathrm{~W} \\
\text { 制 御 盤 } & \text { A B W-M V }
\end{array}
$$

\section{2. $\mathrm{ph}$ 調節計の構成}

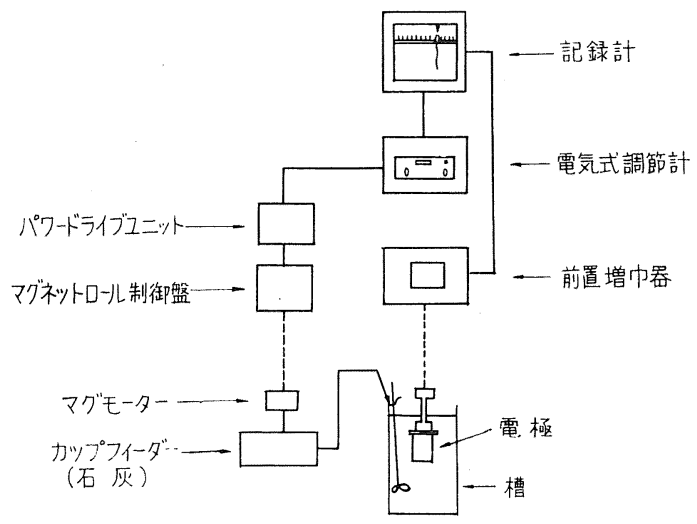

第 2 図 $\mathrm{pH}$ 調 節 計

\section{3. 原理}

\section{(1) 指示記録}

電極に発生した $\mathrm{pH} に よ る$ 起電力は前置増巾器で増 巾され、記録計に入り、指示記録される。一ガラ ス、カロメル両電極間に生じた電圧が増巾されるが、 その際の液の温度の補償は、温度補償電極により自動 補償される。—

記録計は電子管式サーボ機構を利用した方式で精度 が高い。

(2) 調 䬣

指示值と設定指標との偏差が電圧として取出され一 一記録計内の機構により一一電気式調節計に入る。電
気式調節計では、その偏差電王を、交流交換して増巾 し最終段では磁気増巾され、パワードライブユニット の二相サーボモーターに送られる。二相サーボモータ 一には饋還用スライドがあり再び電気調節計にかえり 入力に加えられる。

この間に比例、微分、積分の演算回路が入ってい る。即ち偏差電压が演算回路を通ってサーボモーター を回すととになる。サーボモーターには、マグネット ロール制御盤の可変抵抗器が取付けられているためサ 一ボモーターの回転角度によりマグモーターの回転数 が制御される。つまり設定指標と指針が一致していな い時は、カップフィーダーの回転速度を変えて石死乳 の入る量を加減し一致すれば、その時の速度でカップ フィーダーは持続回転される。

\section{4. 据付使用後の状態}

昭和 35 年11月設置以来、比較的順調に作動している。

$$
\text { III ポイドメーター }
$$

これは、トリコンミルの給鉱量を自動制御するコンス タントフィードウェヤーであって別図の如くメリックス ケールにより、輸送量を測定し、コンベヤーおよびテー ブルフィーダーの速度を制御するあのである。

\section{1. 機構原理}

メリックスケールのディスクの回転は、シンクロ発信 器および受信器により計測側に伝達され、積算計および 発電機 $(G)$ を回転させる。（アンプはサーボ用）発電 機の出力電圧は整流器を通り $0 \sim 10 \mathrm{mV}$ の直流電圧とな り、記録調節計に入り指針をふらせると同時に設定指標 により決められる設定電圧との偏差信号は、調節回路に 入り、比例、積分、微分の各回路を通り $5 \sim 25 \mathrm{~mA}$ の出 力信号となってマグネットロール制御盤に入る。

マグネットロール制御盤は、信号電圧を $0.75 \mathrm{kw} 、 \mathrm{~V}$

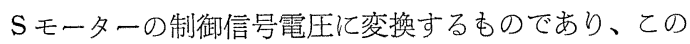
出力により、V S モーターのマグネチックカップリング の磁力が変化し、出力軸の速度が変化する。即ち出力信 号に比例した速度で回転することになる。

$0.75 \mathrm{kw} 、 V ~ S$ モータ一に取付讨られた速度検出用発 電機の出力は整流器を通った後、サイラトロン制御盤に 加えられ、3.7kw、V S モーターの制御用電圧に変換さ れ、VSモーターに与えられる結果、3.7kw、V モ モ一

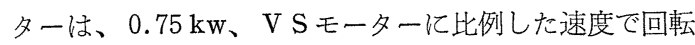
する。即ちコンベヤーおよびテーブルフィーダーは調節 計の出力電圧に比例して回転する。なお、3.7kw、V S モーターに取付けられた発電機の出力が、サイラトロン 制御盤の入力に加えられ、入力電圧と比較されるように 結線されているため、テーブルフィーダーの負荷の変動 による速度変化を少なくすることが出来る。 


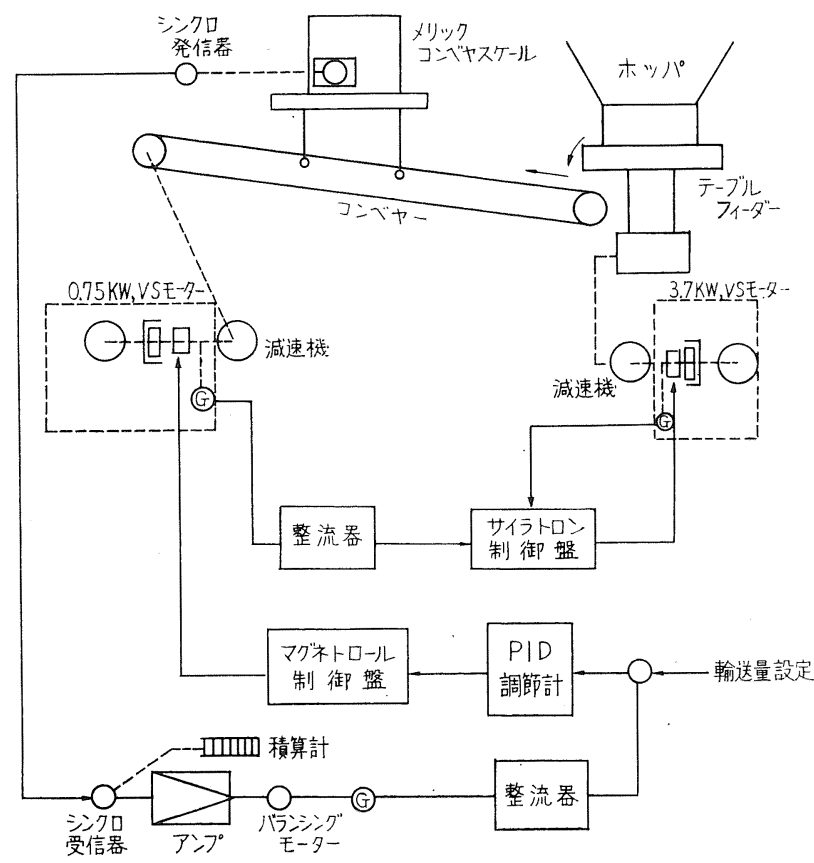

第3図・Ni 選鉱 ポイドメーター制御系統図

2. 仕 樣

製作所……久保田鉄工 $\mathrm{K} \mathrm{K}$

型 式........ $\mathrm{ME}$-6

輸送能力 $\cdots 2 \sim 8 \mathrm{~T} / \mathrm{H}$

ベルトウ $\cdots 500 \mathrm{~mm}$

" 速度…..6.8 1.7m $/ \mathrm{min}$

コンベヤー機長……23. $23 \mathrm{~m}$

" 傾斜……18 $18^{\circ}$
上部供給装置……テーブルフィーダー

同上供給能力 $\cdots \cdots .2 \sim 8 \mathrm{~T} / \mathrm{H}$

秤量部型式……リックスケール

メータ一方向……右側

円盤一回転表示量 $\cdots \cdots \cdot 100 \mathrm{~kg}$

同上、最小目盛. $\cdots . .1 \mathrm{~kg}$

“ 最大累加表示量……10,000Ton

能力調整単位目盛......100kg/H

働 長 $\cdots \cdots .2,400 \mathrm{~mm}$

被 計 量 物……ッケル硫化物

見掛 比……1.5 2.0

粒 度……5mm以下 $(-200 \mathrm{Mesh} 50 \%)$

水 分...... $8 \sim 10 \%$

精 度 $\cdots \cdots \pm 0.1 \mathrm{~T} / \mathrm{H}$ 以内

使用電動機……サイトロン式V S モーター

$3,7 \mathrm{kw} 、$ マグネトロール式V

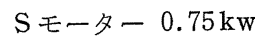

電 源……A C $220 \mathrm{~V} 、 60 \sim$

\section{3. 据付使用後の現状}

昭和35年11月16日より使用している。使用当初 は不慣れによる管理上の問題むあって、凡そ下記 の如き原因による故障を生じたが、現在では順調に作動 している。

（1）故障原因

(a) 粉塵によるV S モーターのカップリング作動不 能

(b) 真空管不良による

(c) 計器自体の故障

(d) テーブルフィーダーの不調

(10頁より続く)

10. シックナーの管理

シックナーの濁面を管理するためにエヤパージ式によ る濁面深度測定装置を自家製作設置し、使用している。 その測定の原理は下式によって表わされる。（第11図 参照)

$\mathrm{H}_{1}=\mathrm{H}_{2}=\mathrm{h}_{1}+\mathrm{h}_{2} \quad \rho_{1}=\rho_{2}-1<\rho_{2}-2$ に扔いて

$\Delta \mathrm{P}=\mathrm{h}_{1} \cdot \rho_{2}-{ }_{1}+\mathrm{h}_{2} \cdot \rho_{2}-{ }_{2}-\mathrm{H}_{1} \cdot \rho_{1}$

$\mathrm{H}_{1}$ : 基準パージ管の挿入深さ

$\mathrm{H}_{2}$ : 測定パージ管の挿入深さ

$\mathrm{h}_{1}: \rho_{2}-1$ 液中のパージ管の挿入深さ

$\mathrm{h}_{2}: \rho_{2}-2$ 液（濁液）中のパージ管の扱入深さ $\rho_{1}:$ 基準液の比重

$\rho_{2}-1:$ シックナー上澄液の比重

$\rho_{2}-2:$ 濁液の比重

$\Delta \mathrm{P}:$ パージ管の背圧の差

すなわち、基準液および測定液に対するエヤーパージ 管の挿入深さが同一、かつ一定であれば基準側に対する 測定側の比重の変化、すなわち濁面の変位は圧力計に差 圧として表わされる。

圧力計に濁面深度目盛を付し直続式としている。

（第27回例会資料「選鉱操業之計測管理」より再録） 